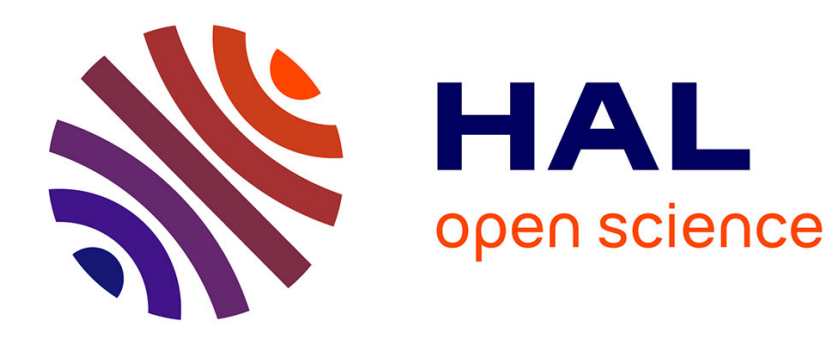

\title{
Size and Scope of the Underground Economy in Germany
}

\author{
Michael Pickhardt, Jordi Sardà Pons
}

\section{To cite this version:}

Michael Pickhardt, Jordi Sardà Pons. Size and Scope of the Underground Economy in Germany. Applied Economics, 2006, 38 (14), pp.1707-1713. 10.1080/00036840500426868 . hal-00581856

\section{HAL Id: hal-00581856 https://hal.science/hal-00581856}

Submitted on 1 Apr 2011

HAL is a multi-disciplinary open access archive for the deposit and dissemination of scientific research documents, whether they are published or not. The documents may come from teaching and research institutions in France or abroad, or from public or private research centers.
L'archive ouverte pluridisciplinaire HAL, est destinée au dépôt et à la diffusion de documents scientifiques de niveau recherche, publiés ou non, émanant des établissements d'enseignement et de recherche français ou étrangers, des laboratoires publics ou privés. 


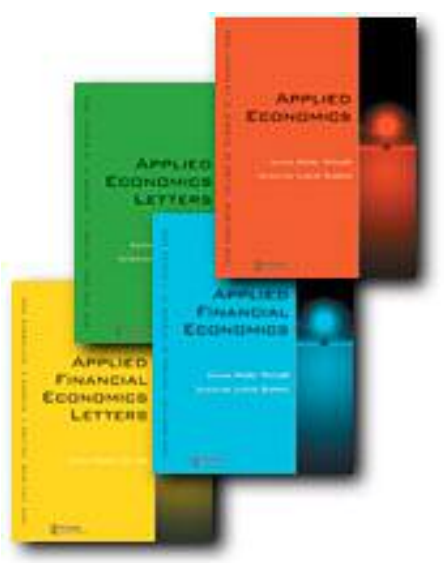

Size and Scope of the Underground Economy in Germany

\begin{tabular}{|c|c|}
\hline Journal: & Applied Economics \\
\hline Manuscript ID: & APE-04-0042.R1 \\
\hline Journal Selection: & Applied Economics \\
\hline $\begin{array}{r}\text { Date Submitted by the } \\
\text { Author: }\end{array}$ & 25-Feb-2005 \\
\hline JEL Code: & $\begin{array}{l}\text { O17 - Formal and Informal Sectors|Shadow Economy|Institutional } \\
\text { Arrangements < O1 - Economic Development < O - Economic } \\
\text { Development, Technological Change, and Growth, H26 - Tax } \\
\text { Evasion < H2 - Taxation, Subsidies, and Revenue }<\text { H - Public } \\
\text { Economics }\end{array}$ \\
\hline Keywords: & Underground Economy, Shadow Economy, Tax Evasion \\
\hline
\end{tabular}

powered by ScholarOne

Manuscript Central 


\title{
Size and Scope of the Underground Economy in Germany
}

\begin{abstract}
The objective of this paper is to improve estimations of the size and scope of the underground economy by introducing a new approach that combines the advantages of the two most commonly used approaches, i.e., currency demand and MIMIC. The new approach is applied to Germany. Among other things, it is shown that the approach yields improved estimation results. Some policy perspectives are discussed in the concluding section.
\end{abstract}




\section{INTRODUCTION}

Estimates of the size of the underground economy by Giles (1999a,b), Schneider and Enste (2000), Schneider and Klinglmair (2004), and others, indicate that the underground economy has risen over the last two decades in virtually all countries under investigation. Yet, in general, estimates of the size of the underground economy seem to be sensitive to the underlying approach that is used. Moreover, even if the relative size of the underground economy is virtually the same, the scope of the underground economy, i.e., the structural, social, geographical, etc., dimension of underground activities, may well differ with respect to the countries under consideration. To this extent, the purpose of this paper is to further improve estimates of the size and scope of the underground economies by introducing a new approach that combines the advantages of the two most commonly used approaches (currency demand and MIMIC). This new methodological aspect is applied to Germany.

The remainder of this paper is organized as follows. The next section introduces the methodology and the third section offers some estimation results. Concluding remarks and some policy perspectives are provided in section four.

\section{METHODOLOGY}

There are several methods of estimating the size and scope of the underground economy. Surveys of the literature on measuring the underground economy are provided by Feige and Ott (1999) or Schneider and Enste (2000), among others. In this paper, the size and scope of the underground economy are estimated by 
using macroeconomic data. In particular, the currency demand approach and the MIMIC approach are employed and a new combination of the latter two is introduced as a third option. All three approaches are discussed in some detail in the following subsections.

\section{The currency demand approach}

The currency demand approach rests on the assumption that cash is the only means of payment used in the underground economy, because cash leaves to traces for the authorities. In addition, it is assumed that taxes are the main reason why people get involved in the underground economy, because in this way they may at least partly avoid paying taxes. Hence, if the tax base is given, increasing (or decreasing) tax rates may induce more (or less) underground economy activities, which in turn may increase (or decrease) the demand for currency. Thus, an equation for currency demand that includes a measure of fiscal pressure, which is composed of various tax items, and some standard variables such as income, prices and interest rates, is econometrically estimated over time.

Following Mauleón and Escobedo (1991) and Mauleón and Sardá (1997, 2000), the demand for currency is specified in log-linear terms, that is:

$$
\log \left(E_{t}\right)=\alpha_{0}+\alpha_{1} \cdot \log \left(Y_{L t}\right)+\alpha_{2} \cdot \log \left(P_{t}\right)+\alpha_{3} \cdot c_{t}+\alpha_{4} \cdot R_{t}+u_{t},
$$

where $E$ is currency demand, $Y_{L}$ is observed legal income in terms of GDP, $P$ is a price index, $c$ is a measure of fiscal pressure composed of various tax system variables, $R$ is the nominal interest rate, $\alpha_{0-4}$ are parameters to be estimated, $u$ is 
the error term and the subscript $t$ refers to time. Reversing the logarithmic transformation in (1) yields:

$$
E_{t}=\alpha_{0} \cdot Y_{L t}^{\alpha 1} \cdot P_{t}^{\alpha 2} \cdot \exp \left(\alpha_{3} \cdot c_{t}+\alpha_{4} \cdot R_{t}+u_{t}\right)
$$

As variations in tax rates are assumed to cause fluctuations in the demand for currency attributable to the underground economy, it follows that the demand for currency attributable to total income, underground $Y_{U}$ and observed $Y_{L}$, is given by (3), if there are no taxes:

$$
E_{t}=\alpha_{0 \cdot}\left(Y_{L t}+Y_{U t}\right)^{\alpha 1} \cdot P_{t}^{\alpha 2} \cdot \exp \left(\alpha_{4} \cdot R_{t}+u_{t}\right)
$$

Equating (2) and (3) and rearranging yields:

$$
Y_{U t} / Y_{L t}=\exp \left(\alpha_{3} \cdot c_{t} / \alpha_{1}\right)-1 \approx \alpha_{3} \cdot c_{t} / \alpha_{1}
$$

where the size of the underground economy is explained as a function of fiscal pressure $c$, and the size of the underground economy, $Y_{U t}$, is measured as a fraction of the observed economy, $Y_{L t}$.

Note that this version of the currency demand approach neither requires a reference year in which the size of the underground economy is assumed to be zero nor does it require that the velocity of cash circulation is the same in both the legal and the underground sector of the economy. Likewise, if the modeling of currency demand includes additional variables, for example, financial innovations as in Hill and Kabir (2000: 184), it is not necessary to assume that these variables 
affect both sectors of the economy in a similar way. However, among other things, the currency demand approach is often criticized on the grounds that it focuses on just one cause of underground activities (taxation), and on just one indicator (fiscal pressure induced by the tax system) of underground activities (Schneider and Enste, 2000: 94-96). For this reason, the MIMIC approach is considered in the following subsection.

The MIMIC approach

In contrast to the currency demand approach, the MIMIC approach allows for several indicator variables and several causal variables in forming structural relationships to explain a latent variable, for example, the size of the underground economy.

Following Giles (1999a,b), Tedds and Giles (2000: 3-4) and others, a standard MIMIC model is formulated as follows. The size of the underground economy, $\eta$, is defined as a scalar latent variable, with $\boldsymbol{y}^{\prime}=\left(y_{1}, y_{2}, \ldots, y_{p}\right)$ and $\boldsymbol{x}^{\prime}=\left(x_{1}, x_{2}, \ldots, x_{q}\right)$ representing vectors of indicators and causes of $\eta$ respectively. Likewise, $\lambda$ and $\gamma$ are $(p x l)$ and $(q x l)$ vectors of parameters, $\varepsilon$ is a $(p x l)$ random error, $\xi$ is a scalar random error and both error terms are assumed to be normal and mutually uncorrelated, with $\operatorname{var}(\xi)=\psi$, and $\operatorname{cov}(\varepsilon)=\Theta_{\varepsilon}$. The MIMIC model is then specified as:

$$
\begin{aligned}
& \mathbf{y}_{t}=\lambda \eta_{t}+\varepsilon_{t}, \\
& \eta_{t}=\gamma^{\prime} x_{t}+\xi_{t}
\end{aligned}
$$


Substituting (6) into (5) yields,

$$
\mathbf{y}_{t}=\Pi x_{t}+z_{t}
$$

where:

$$
\begin{aligned}
& \Pi=\lambda \gamma^{\prime}, \\
& z_{t}=\lambda \xi_{t}+\varepsilon_{t},
\end{aligned}
$$

and:

$$
\operatorname{cov}(\boldsymbol{z})=\lambda \psi \lambda \boldsymbol{\lambda}+\Theta_{\varepsilon}
$$

The rank of the regressor matrix, $\Pi$, of the $p$-equation multivariate regression model (7), is equal to 1 and the error covariance matrix, $\operatorname{cov}(\boldsymbol{z})$, is also constrained. Hence, a normalization of one of the elements of the vector $\lambda$ to some pre-assigned value is required prior to the estimation of (7). Estimates of the elements of $\Pi$, and thus of $\lambda$ and $\gamma^{\prime}$, can then be obtained through a restricted Maximum Likelihood estimation. Next, ordinal values for the latent variable, $\eta$, can be derived from equation (6), if the error term $\xi$ is set to zero. However, the ordinal values obtained for $\eta$ must be transformed into cardinal values and this inevitably requires a cardinal reference value for $\eta$ at a sample point, i.e., usually the base year of the period under consideration. But it is important to note that this cardinal reference value or benchmark must be obtained from an external source, for example, the currency demand approach.

Yet, despite its advantages, the MIMIC approach may be criticized for being too sensitive to the causes and indicators under consideration, the benchmark that 
is used and the transformation process that is required. Given the criticism of both the currency demand approach and the MIMIC approach, in the next subsection, it is proposed to combine the two approaches in order to overcome some of the disadvantages.

The joint model

The new methodological aspect introduced here consists of estimating the currency demand model jointly with the MIMIC model. More precisely, expression (1) is considered as an additional equation of the $p$-equation multivariate regression model (7), which yields the $(p+1)$-equation multivariate regression model (11), hereafter referred to as the joint model:

$$
\begin{aligned}
& \boldsymbol{y}_{\boldsymbol{t}}=\boldsymbol{\Pi} \boldsymbol{x}_{\boldsymbol{t}}+\boldsymbol{z}_{\boldsymbol{t}} \\
& \log \left(\mathrm{E}_{\mathrm{t}}\right)=\alpha_{0}+\alpha_{1} \cdot \log \left(\mathrm{Y}_{\mathrm{Lt}}\right)+\alpha_{2} \cdot \log \left(\mathrm{P}_{\mathrm{t}}\right)+\alpha_{3} \cdot \mathrm{c}_{\mathrm{t}}+\alpha_{4} \cdot \mathrm{R}_{\mathrm{t}}+\mathrm{u}_{\mathrm{t}}
\end{aligned}
$$

Hence, the new aspect consists of adding information to the system of equations in (7) and this should improve the robustness of the estimation. In fact, as the following section shows, a SURE estimation procedure of the joint model (11) yields improved estimation results. In addition, the procedure addresses the calibration problem which is usually encountered with a MIMIC model, i.e., converting the resulting index into a series of levels.

\section{ESTIMATION RESULTS}


Given the limited availability of quarterly time series data for several variables, all models have been estimated with annual data from 1980 to 2001, using the EViews 4.1 software package. Data sources and definitions of all variables are provided in the appendix.

The currency demand model

Regarding the currency demand model the estimations demonstrate reasonable statistical properties. Table 1 shows the results obtained from estimating equation (1).

***Insert Table 1 about here***

Yet, the values of the income and price elasticity's differ from their usually expected value of unity, and the difference is particularly unexpected with regard to the income elasticity. But it may well be that these values capture those underground activities which are not affected by the evolution of the tax system, i.e., the fiscal pressure variable. An additional or alternative explanation might be that these values capture currency demand motives other than the transaction motive. For example, speculative cash holdings in the legal economy during periods of very low interest rates or other wealth related speculative motives.

The MIMIC model 
We have used the natural logarithm of the GDP growth rate, the male labour force participation rate, and the natural logarithm of cash as indicators. The causal variables for Germany are: inflation, unemployment, the number of full-time employees and various taxes. As noted, we need to constrain the coefficient of one variable to solve the models and for this reason we have constrained the male labour force participation rate to unity. As a consequence, all values obtained for the coefficients must be interpreted relative to this normalization. Also, we have considered several MIMIC model specifications. Tables 2 shows the results for Germany.

***Insert Table 2 about here***

In Table 2 the positive sign of the LogGDP variable in all model specifications indicates that there is a positive relation between the growth rate of the observed real GDP and the size of the underground economy. Based on the statistical properties, our preferred specification is model 2. According to model 2, only three variables explain about two thirds of the size of the underground economy in Germany. These three variables are taxes (34.4 percent), price indices (21.2 percent) and labour market variables (i.e. unemployment and fulltime) (10.4 percent). Moreover, with respect to taxes model 4 suggests that 52.0 percent of the tax effect is explained by social security taxes (or payments), 30.8 percent by indirect taxes and just 17.2 percent by direct taxes.

Finally, Table 3 demonstrates that improved estimation results can be obtained with the joint model (11). 
***Insert Table 3 about here***

Underground economy calculations

With bearing the reservations mentioned in section II in mind and by applying the methodology discussed in section II, an estimation of the size of the underground economy in Germany can be obtained. In particular, applying the estimation results shown in Table 1 to equation (4), Table 2 (Model 2) to equation (5), and Table 3 to equation (11) yields Table 4.

***Insert Table 4 about here***

According to Table 4 the estimated relative size of the underground economy in Germany varies with the model under consideration. However, there are only a few minor differences among the three models. In particular, the MIMIC model yields slightly higher figures than the currency model throughout the entire sample period, whereas the figures of the joint model fall in between, except in 1991, but are usually closer to the figures of the currency model. Over the sample period 1980-2001, the size of the German underground economy peaks in 1999 and this result is true for all three models. The results in Table 4 also suggest that the reunification of Germany in 1990 had a substantial impact on the growth of the German underground economy. Figure 1 visualizes the evolution of the underground economy in Germany over time.

***Insert Figure 1 about here*** 
The results in Table 4 and Figure 1 confirm the findings of Schneider and Enste (2000) and Schneider and Klinglmair (2004) with respect to the relative size of the German underground economy.

\section{CONCLUDING REMARKS AND POLICY PERSPECTIVES}

According to the results presented in this paper the relative size of the underground economy in Germany increased over time until 1999 and then dropped back to its 1996 level in 2001. Giles (1997) reports similar movements in the time-path of the New Zealand underground economy between 1987 and 1992, and finds evidence of Granger-causality from the measured to the underground economy. In addition, Giles (1999c) finds no evidence that an increase or decrease in real GDP causes asymmetric responses in the underground economy of New Zealand. Both findings have important implications for the use of fiscal policy as an instrument for controlling the size of the underground economy (Giles and Caragata, 2001; Giles, Tedds and Werkneh, 2002). Moreover, according to Giles and Caragata (2001: 1863) the ratio of underground to measured GDP and the ratio of total tax revenue to GDP are cointegrated in the case of New Zealand, which implies that any exogenous shock to the system will be absorbed and the two variables never drift apart. As demonstrated in this paper, the exogenous shock "reunification" had a substantial impact on the ratio of underground to measured GDP in Germany. Thus, the German case seems to be particularly suitable for applying the methods of Giles $(1997,1999 \mathrm{c})$ and Giles and Caragata 
(2001). Any confirmation of their results would have important implications for controlling the size of the German underground economy via fiscal policy.

Regarding the scope of the underground economy, the results indicate that taxes explain more than a third of the German underground economy. Yet, more than 50 percent of the tax effect is explained by social security taxes. These payments, however, are directly linked to the labour market as they are economically born by both the employer and the employee (50 percent each), but transferred to the responsible social security body exclusively by the employer. As noted, another 10 percent of the underground economy in Germany is explained by other labour market variables. Hence, in the German case, labour market policy may be an important alternative or complement to fiscal policy as an instrument for controlling the size of the underground economy.

Finally, the findings in this paper suggest that both the size and the scope of a country's underground economy may serve as an indicator for a country specific social reform agenda, which in turn would allow for constructing a social reform index. In such an index the scope of the underground economy could well serve as a mirror imaged blueprint for the type of social reforms need in a country, while its relative size and its growth rate would hint at how urgent these reforms are. Yet, the construction of such an index would certainly require searching for more variables that can be used to determine the scope of the underground economies in order to get a more comprehensive and complete image of the latter. Likewise, the conjecture that the joint model approach yields more efficient estimates, calls for applying the joint model approach to more countries. But these tasks delineate a future research agenda. 


\section{ACKNOWLEDGEMENTS}

The authors are indebted to Axel Dreher, Andrea Gebauer, Ignacio Mauleón, Michael Neugart, and an anonymous referee for valuable comments and suggestions. However, any shortcomings are the authors' sole responsibility. Sardà is grateful to the DAAD for grant No 314/2002.

\section{APPENDIX}

\section{VARIABLES}

Cash $=$ Currency, notes and coins, in circulation; D1 = dummy taking into account the German reunification; Deuro $=$ dummy that takes into account the stablishment of the euro; Fulltime $=$ Full time workers/total labour force; $G D P=$ Real Gross Domestic Product (1995); $M R=$ male labour participation rate; $P=$ Price index. Here, Consumer's Price Index (CPI) (1995); $R c=90$ Day Treasury Bill Rate; SSTax $=$ Tax revenue $:=$ Social Security contributions/GDP; TdTax $=$ Tax revenue $:=$ total direct taxes/GDP; TiTax $=$ Tax revenue $:=$ total indirect taxes/GDP; TotalTax $=$ SSTax + TdTax + TiTax; Unemp = unemployment (\%);

\section{DATA SOURCES}

Germany - Cash: Statistisches Jahrbuch 1960-2002, Bundesamt für Statistik; CPI, GDP, Fulltime, MR, Rc, Unemp: OECD Statistical Compendium 1/2002; SSTax, TdTax, TiTax: Statistisches Jahrbuch 1979-2002, Bundesamt für Statistik. 


\section{REFERENCES}

Feige, E. L. and Ott, K. (Eds.) (1999) Underground economies in transition. Aldershot: Ashgate.

Giles, D.E.A. (1997) Causality between the measured and underground economies in New Zealand, Applied Economics Letters, 4, 63-67.

Giles, D.E.A. (1999a) Modeling the hidden economy and the tax-gap in New Zealand, Empirical Economics, 24, 621-640.

Giles, D.E.A. (1999b) Measuring the hidden economy: Implications for econometric modeling, Economic Journal, 109, 370-380.

Giles, D.E.A. (1999c) The Rise and Fall of the New Zealand Economy: Are the Responses Symmetric?, Applied Economics Letters, 6, 185-189.

Giles, D.E.A. and Caragata, P.J. (2001) The Learning Path of the Hidden Economy: Tax and Growth Effects in New Zealand, Applied Economics, 33, $1857-1867$.

Giles, D.E.A., Tedds, L.M. and Werkneh, G.T. (2002) The Canadian Underground and Measured Economies: Granger Causality Results, Applied Economics, 34, 2347-2352.

Hill, R. and Kabir, M. (2000) Currency demand and the growth of the underground economy in Canada 1991-1995, Applied Economics, 32, 183192.

Mauleón, I. and Escobedo, I. (1991) Demanda de dinero y economía sumergida, Hacienda Pública Española, 5, 105-122. 
Mauleón, I. and Sardà, J. (1997) Estimación cuantitativa de la economia sumergida en España, Ekonomiaz, 39, 125-134.

Mauleón, I. and Sardà, J. (2000) Income Measurement and Comparisons, International Advances in Economic Research, 6, 475-487.

OECD. OECD Statistical Compendium 2001.

Schneider, F. and Enste, D. (2000) Shadow Economies: Size, Causes and Consequences, Journal of Economic Literature, 38, 77-114.

Schneider, F. and Klinglmair, R. (2004). Shadow economies around the world: What do we know? IZA Discussion Paper No. 1043. Bonn: Institute for the Study of Labor.

Tedds, L.M. and Giles, D.E.A. (2000). Modeling the Underground Economies in Canada and New Zealand: A Comparative Analysis, Econometrics Working Paper EWP0003, Department of Economics, University of Victoria, Canada. 
Table 1. Currency demand model

\begin{tabular}{ccc} 
Variables & coefficient & t-statistics \\
\cline { 2 - 3 } Constant $\left(\alpha_{0}\right)$ & $-15.565^{*}$ & $(-3.36)$ \\
LogGDP $\left(\alpha_{1}\right)$ & $0.716^{*}$ & $(3.73)$ \\
LogP $\left(\alpha_{2}\right)$ & $1.406^{*}$ & $(4.30)$ \\
TotalTax $\left(\alpha_{3}\right)$ & $2.378^{*}$ & $(2.70)$ \\
Rc $\left(\alpha_{4}\right)$ & $-0.008^{* *}$ & $(-1.79)$ \\
D1 & $0.274^{*}$ & $(3.85)$ \\
Deuro & $0.126^{*}$ & $(4.90)$ \\
\hline & & \\
R & 0.99 & \\
Adj. R & 0.99 & \\
F & 65.44 & \\
s.e. & 0.034 & \\
RESET & 0.22 & \\
JB & 0.36 & \\
\hline
\end{tabular}

Notes. $\mathrm{N}=21 . \mathrm{A} *, * *$ or $* * *$ respectively indicates significance at $.01, .05$ or .10 for a one-sided t-test. 
Table 2. MIMIC results for Germany

\begin{tabular}{|c|c|c|c|c|}
\hline Model & 1 & 2 & 3 & 4 \\
\hline \multicolumn{5}{|l|}{ Indicators } \\
\hline \multirow[t]{2}{*}{ Log GDP } & $0.028^{*}$ & $0.028^{*}$ & $0.029^{*}$ & $0.028^{*}$ \\
\hline & (207) & (207) & $(207)$ & $(207)$ \\
\hline \multirow[t]{2}{*}{ MR } & 1.000 & 1.000 & 1.000 & 1.000 \\
\hline & $(-)$ & $(-)$ & $(-)$ & $(-)$ \\
\hline LogCash & & - & $\begin{array}{l}0.069^{*} \\
(92.7)\end{array}$ & - \\
\hline \multicolumn{5}{|l|}{ Causes } \\
\hline \multirow[t]{2}{*}{$\log \mathrm{P}$} & $0.206^{*}$ & $0.220^{*}$ & $0.213^{*}$ & $0.240^{*}$ \\
\hline & (79.4) & $(17.2)$ & $(15.6)$ & $(14.0)$ \\
\hline \multirow[t]{2}{*}{ TotalTax } & $0.350^{*}$ & $0.357^{*}$ & $0.345^{*}$ & - \\
\hline & $(5.95)$ & $(6.20)$ & $(5.57)$ & \\
\hline \multirow[t]{2}{*}{ Unemp } & $-0.280^{*}$ & $-0.353^{*}$ & $-0.348^{*}$ & $-0.608^{*}$ \\
\hline & $(-6.31)$ & $(-10.3)$ & $(-4.02)$ & $(-4.29)$ \\
\hline \multirow[t]{2}{*}{ Fulltime } & - & $-0.047^{* * *}$ & -0.036 & $-0.163^{*}$ \\
\hline & & $(-1.06)$ & $(-0.75)$ & $(-2.74)$ \\
\hline \multirow[t]{2}{*}{ D1 } & $0.059^{*}$ & $0.061^{*}$ & $0.056^{*}$ & $0.012^{*}$ \\
\hline & $(9.21)$ & $(9.30)$ & $(7.84)$ & $(2.52)$ \\
\hline \multirow[t]{2}{*}{ SSTax } & - & - & - & $0.588^{*}$ \\
\hline & & & & $(3.90)$ \\
\hline \multirow[t]{2}{*}{ TdTax } & - & - & - & 0.194 \\
\hline & & & & $(0.75)$ \\
\hline \multirow[t]{2}{*}{ TiTax } & - & - & - & $0.348^{*}$ \\
\hline & & & & $(2.22)$ \\
\hline $\mathrm{Chi}^{2}$ & 13.14 & 26.56 & 21.28 & 23.45 \\
\hline p-value & 0.86 & 0.40 & 0.78 & 0.42 \\
\hline RMSEA & 0.0 & 0.0 & 0.0 & 0.0 \\
\hline RMR & 0.02 & 0.05 & 0.02 & 0.06 \\
\hline AGFI & 0.85 & 0.87 & 0.82 & 0.87 \\
\hline
\end{tabular}


Table 3. Joint Model results for Germany

\begin{tabular}{|c|c|c|c|}
\hline \multicolumn{2}{|c|}{ MIMIC } & \multicolumn{2}{|c|}{ Currency } \\
\hline Indicators & coefficient & Variables & coefficient \\
\hline Log GDP & $\begin{array}{c}0.028^{*} \\
(207)\end{array}$ & $\operatorname{Constant}\left(\alpha_{0}\right)$ & $\begin{array}{c}-17.111^{*} \\
(-4.51)\end{array}$ \\
\hline MR & $\begin{array}{c}1.000 \\
(-)\end{array}$ & $\operatorname{LogGDP}\left(\alpha_{1}\right)$ & $\begin{array}{l}0.790^{*} \\
(5.03)\end{array}$ \\
\hline & & $\operatorname{LogP}\left(\alpha_{2}\right)$ & $\begin{array}{l}1.245^{*} \\
(4.73)\end{array}$ \\
\hline Causes & & TotalTax $\left(\alpha_{3}\right)$ & $\begin{array}{l}2.678^{*} \\
(3.74)\end{array}$ \\
\hline $\log P$ & $\begin{array}{l}0.234^{*} \\
(14.8)\end{array}$ & $\operatorname{Rc}\left(\alpha_{4}\right)$ & $\begin{array}{l}-0.004 \\
(-1.20)\end{array}$ \\
\hline Unemp & $\begin{array}{l}-0.592^{*} \\
(-4.51)\end{array}$ & D1 & $\begin{array}{l}0.285^{*} \\
(4.17)\end{array}$ \\
\hline D1 & $\begin{array}{l}0.011^{*} \\
(2.41)^{4}\end{array}$ & Deuro & $\begin{array}{l}0.130^{*} \\
(6.46)\end{array}$ \\
\hline Fulltime & $\begin{array}{l}-0.146^{*} \\
(-2.67)\end{array}$ & & \\
\hline SSTax & $\begin{array}{l}0.578^{*} \\
(4.33)\end{array}$ & & \\
\hline TdTax & $\begin{array}{l}0.150 \\
(1.20)\end{array}$ & & \\
\hline TiTax & $\begin{array}{c}0.315^{* *} \\
(2.17)\end{array}$ & & \\
\hline $\mathrm{Chi}^{2}$ & 23.83 & & \\
\hline p-value & 0.43 & & \\
\hline RMSEA & 0.0 & & \\
\hline RMR & 0.06 & & \\
\hline AGFI & 0.94 & & \\
\hline
\end{tabular}


Table 4. Relative size of the underground economy in Germany (1980-2001)

\begin{tabular}{cccc}
\hline & & & \\
& & & \\
& Currency & MIMIC (2) & Joint Model \\
Year & (\% of GDP) & (\% of GDP) & (\% of GDP) \\
\hline & & & \\
1980 & 9.41 & 9.41 & 9.41 \\
1981 & 9.40 & 9.46 & 9.45 \\
1982 & 9.40 & 9.50 & 9.46 \\
1983 & 9.43 & 9.55 & 9.48 \\
1984 & 9.63 & 9.83 & 9.69 \\
1985 & 9.86 & 10.10 & 9.92 \\
1986 & 9.87 & 10.11 & 9.92 \\
1987 & 10.09 & 10.35 & 10.15 \\
1988 & 10.45 & 10.77 & 10.52 \\
1989 & 10.76 & 11.19 & 10.83 \\
1990 & 10.90 & 11.39 & 10.96 \\
1991 & 13.08 & 13.10 & 13.15 \\
1992 & 13.97 & 14.17 & 14.05 \\
1993 & 13.95 & 14.19 & 14.03 \\
1994 & 14.24 & 14.55 & 14.32 \\
1995 & 14.70 & 15.12 & 14.79 \\
1996 & 15.29 & 15.81 & 15.38 \\
1997 & 15.29 & 15.80 & 15.38 \\
1998 & 15.30 & 15.83 & 15.38 \\
1999 & 15.74 & 16.38 & 15.83 \\
2000 & 15.61 & 16.29 & 15.70 \\
2001 & 15.18 & 15.84 & 15.27 \\
\hline & & & \\
\hline
\end{tabular}




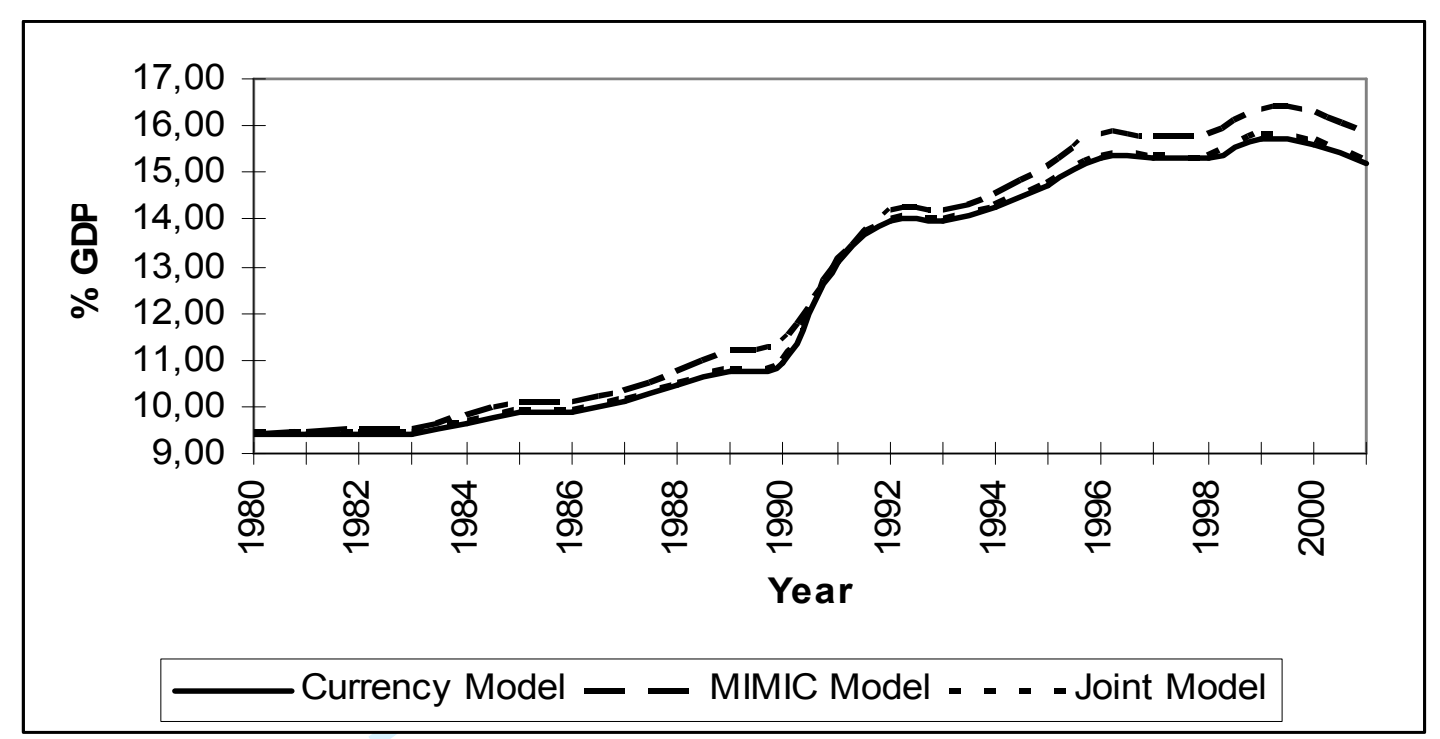

Fig. 1. Size of the underground economy in Germany (1980-2001) in percent of official GDP 